\title{
Rural Health Care Workers and Local Residents Health Status in Yulong County of Yunnan Province China and Hat Yai City of Songkhla Mansion Thailand
}

\author{
QU Fanwei, ${ }^{1}$ JIANG Yanling, ${ }^{2}$ Virasakdi Chongsuvivatwong, ${ }^{3}$ Tippawan Liabsuetrakul, ${ }^{4}$ LI Yan, ${ }^{5}$ CAI Le, ${ }^{6}$ \\ JIANG Runsheng ${ }^{7}$ \\ 1,2,5,6,7, Kunming Medical University, 1168 West Chunrong Road, Yuhua Avenue, Chenggong District, Kunming 650500, \\ Yunnan,P.R. China, ${ }^{3,4}$ Epidemiology Unit, Faculty of Medicine, Prince of Songkla University, Hat Yai, Songkhla 90110, \\ Thailand.
}

\section{ABSTRACT}

Introduction: To compare health status between Hat Yai city of Songkhla Province in Thailand and Yulong county of Yunnan province in China about rural health care workers and local residents, analyzing of both differences, learning from the advanced experience and practice of Thailand, adjusting policy, especially for the implementation of measures to improve the lack of human resources construction of Yulong County rural health, promote the level of rural health service of Lijiang.

Methods: A qualitative study consisting of focus group discussions and individual in-depth interviews were conducted in Rural Health Care Workers and Local Residents Health Status in Yulong County of Yunnan Province China and Hat Yai City of Songkhla Mansion Thailand from.

Results: Compared to $41(100 \%)$ bachelor's degree of medical staffs in Hat Yai, this accounted only $94(42 \%)$ bachelor's degree of medical staffs in Yulong county hospital, and 31 (12\%)in townships hospitals. For medical workers in Hat Yai, they have at least one time on-job training per year, but for Yulong county, only 144 (29\%)of the medical personnel participated in the training per year. Health expenditures of Yulong county was mainly borne by the local government, and medical insurance coverage rate is 217,107 (99\%). Insurance average awareness of Hat Yai is 4449 (66.4\%), Yulong County is $62,501(28.5 \%), \mathrm{P}<0.001$, there are statistically significant differences between two cities.

Conclusions: Thailand has good experience in training, well-paid, motivating and retaining talent for rural health human resources; multi-pronged, mechanism innovation, establish and perfect the system of human resources for health, is the essential way to solve the problem.

Keywords: Hat Yai city; Yulong County; Rural medical staff; Variance analysis.

\section{INTRODUCTION}

Yunnan province is one of relatively poor frontier provinces in China, and also is one of the few ethnic enclave provinces. There is lack of qualified health personnel and are mainly composed of the primary health personnel.1-3 Most of the bachelor degree or above are mainly concentrated in county hospital attributing to many health issues. ${ }^{4}$

Thailand has a long history in the development of rural health system and rural health human resources, and

Correspondence: JIANG Runsheng,President Offce, Kunming Medical University, 1168 West Chunrong Road, Yuhua Avenue, Chenggong District, Kunming 650500, Yunnan, P.R.China. Email: jrunsheng@sina.com, Phone: +86-871-13908840130. 
has successful experience in the health funding and forced doctors to work in the countryside. In 1967, in response to the condition of lack of rural doctors, the Thai government implemented a policy which sent new graduate medical students to work in rural areas for 3 years compulsorily, enrolled more rural background medical students, set up medical colleges outside big cities, and arranged students to do rotational internship in rural medical institutions during study period. ${ }^{5}$ More than two-thirds of the medical students worked in the countryside after graduation. On this basis, a series of combined policy implementation, ${ }^{6-8}$ began gradually from 1975, implemented the compulsory service and rural doctor incentives policies. In 2001, the Thai government adopted a policy of universal insurance, and health insurance coverage is now close to $100 \%,{ }^{9}$ which greatly improved the health service utilization.

This study aim to compare and contrast the health between China and Thailand at local level.

\section{METHODS}

A qualitative study was conducted in Rural Health Care Workers and Local Residents Health Status in Yulong County of Yunnan Province China and Hat Yai City of Songkhla Mansion Thailand from 2011 to 2013. Ethical approval was taken from ethics committee review of Kunming Medical University. The qualitative research methods used were focus group discussions and individual in-depth interviews for different levels of leaders and medical staff in Yulong county of China and Hat Yai city of Thailand. Quantitative research mainly adopted questionnaire for health workers and local residents. We organize training for investigators, and make a preliminary investigation before the formal investigation, in order to modify the deficiency of the basic rules of questionnaire and interview outline.

We select Hat Yai city of Thailand and Yulong county of China as the study sites, and carried out the survey from May 3 to 11 of 2011 in China compared and in Hat Yai city of Thailand which was selected randomly from January 16 to 18 of 2013. We investigated all the on-the-job medical personnel of 16 townships in Yulong county. We investigated 6 administrative staff, 224 county hospital staff, 256 townships staff and 64 village doctor, 544 in total, and selected two villages in each township randomly, and surveyed residents at least 18 years of age, surveyed 300 households in total in Yulong of China through the method of cluster sampling for community residents.

We adopted the method of simple random sampling in the area of 17 villages according to household unit, extracted 942 residents from 211 families. Representative of household answered the questionnaire. We investigated
10 medical staff in two community hospitals.

All the data entry database, using SPSS17.0 software package for statistical analysis, including descriptive analysis and chi-square test, inspection level for $\mathrm{P}=0.05$.

\section{RESULTS}

Yulong county: We investigated 6 administrative staffs, 224 county hospital staffs, 256 townships staffs and 64 village doctors in total. There are average 3.26 per thousand population with technical personnel in whole county, 819 open beds. The ratio of doctors and nurses is 1:0. 7 in the whole county, the ratio of doctors and nurses at the county level is $1: 0.69$, the ratio of doctors and nurses at township level is 1:0.72., and at village level is $1: 0.56 .315(96 \%)$ staff in county hospital have license but only $257(84.1 \%)$ townships hospital staff have qualification certificate.

Hat Yai: The organizations which represented each level of health system in Songkhla province were chosen were; administrative office for health resources (Songkhla provincial health office), administrative office for health insurance (National Health Security Office: NHSO), regional hospital (Hat Yai hospital), provincial hospital (Songkhla hospital), three district hospitals (Chana hospital, Natawee hospital and Sadao hospital), three sub-district hospitals (Sapaanmaikan sub-district hospital, Bantung sub-district hospital and Prik subdistrict hospital).

From July 25-August 1, 2011, 60 informants were interviewed in total. They are divided into seven management and planning staffs (three from human resource and four from health finance) 39 health personnel (nine doctors, six Nurses, three pharmacists, three dentists and 18 health workers) and 24 patients (Table 1).

Medical insurance has already realized full cover, forms medical insurance also diversification, and formed a perfect health care system. Thai government highly supports health, and the budget for health investment in Thailand for health insurance is about $9 \%$ of GDP, presents good health at low costs. In 2010, the coverage of population with health care was $99.5 \%$ in Thailand. There are three main schemes of health insurance in Thailand. CSMBS system: Mainly applied to on-the-job personnel of the government and their families. SSS system: Mainly Suitable for private enterprise employees and UC scheme: Universal health care

Thailand has set up a good model of medical education for rural doctors carried out by non -university hospitals. 
Thailand has performed a collaborative project to increase production of rural doctors (CPIRD) since 1994. Not only medical universities produce medical students, but also hospitals produce. The concept of CPIRD is: local recruitment, local study and hometown placement with good attitude of working in community.

Thailand has good experience of human resources for health production, deployment and retention for rural communities. Thailand has a unique experience in attracting and retaining health talents for rural areas. All medical students are required to go for grassroots service for three years after six years study, and only then they are eligible to participate in the training of specialized subject. This measure guaranteed the quantity of health human resources in rural areas. The medical staffs who worked at the grass-root level of rural areas, got 3 to 5 times more salary than in big cities, thus receiving monetary incentives. Secondly, Thailand also took spiritual incentive measures, such as setting examples, evaluation of advanced employees, thus giving incentive from the spiritual point of view. In addition, the Thai government has also taken on unitary cultivation pattern, recruited local students from the countryside, signed a contract, which included tuition, the cost of living free for them during their study period. Thus the contract made students return to local rural areas to work for at least 6 years after graduation.

Set up a perfect medical services system. Thailand implemented a three-level- management system in the health field, namely the central place, a provincial and local government, and they have very close collaborative relationship among each level. Thailand deployed corresponding health service agencies according to the administrative areas, and has strictly referral system, pay system (i.e. if the primary hospital can not treat the patients, transfer to superior hospital directly, but fees shall be borne by the junior hospital), medical insurance system (according to the signed contract to promote or constraint hospital's medical quality management in order improve management efficiency, etc.), drug security system, the hospital service flow, etc.

The establishment of a complete public health service system. From the CDC to the medical institutions are clear about the concrete function of the public health service, adopting hierarchical management, making the plan of public health, carrying out public health regulations, assessment evaluation and supervision, to ensure that the whole structure can play reasonable benefits.

Established a perfect information system. From the top level of medical and health institutions to the primary health care center, the government built a perfect medical insurance system, medical education system, medical security system, the patient information sharing and internal and external process of hospital management information system. These systems formed a data networking, set up a green channel and improved the labor and effect.

Found sources: Most come from local government in Yulong, Lijiang, China. However, it comes from the National Health Security Office, Songkhla in Hat Yai of Thailand.

Referral of patients: They need follow the sequence of referral system without any fees in China. However, they need follow the sequence of referral system, and the medical services unit will charge from Songkhla provincial health office every time.

Health insurance of patients: $99 \%$ under NRCMS with co-payment, $75 \%$ "too shallow benefit package" and $13 \%$ "complicated reimbursement" in China. However, the government will pay almost all fees through universal coverage of health insurance, and the patients only have minimal out-of-pocket payment in Thailand.

This survey covered all of the 16 townships in Yulong of Lijiang, using the method of probability proportionate to size sampling, drawn 20 administrative villages from all the villages, and selected 15 households to investigate randomly, a total of 300 households. Finally 1186 people participated this investigation, an average of 3.95 people for each household.

Totla 1186 surveyed people in China, 570 male, accounting for $48.1 \%$; 616 female, accounting for $51.9 \%$, women slightly more than men, which means male often go out to work, not at home (Table 2).

The residents in Yulong county still need to pay $8 \%$ of the medical expenses in 2011, however, residents in Hat Yai city only have tiniest economic burden, after paying the cost of 30 baht, the rest of the fees is borne by the government basically (Table 3). According to annual report of public health development in 2015 of Yulong county, the new rural cooperative medical system (NCMS) rate has reached $99.98 \%$ in 2015, 5.38\% higher than five years ago. Number of participants is 192617 , per capita financing standard is $470 \mathrm{RMB}$, including the central and provincial subsidy of $380 \mathrm{RMB}$, personal raised $90 \mathrm{RMB}$. Total fund is 90.558 million RMB, which is 45.96974 million $\mathrm{RMB}$ more than five years ago, increased by $50.8 \%$. For some very poor population 38614 in total, such as low-income residents, the government will pay the money for them, 3.47526 million RMB. Since major commercial supplementary insurance carried out from 2104 , individual security capacity has reached 300000 $\mathrm{RMB}$, highest personal hospitalization expense payment 
ratio above $75 \%$, actual cost of individual hospital reimbursement rate above $60 \%$. The implementation of the new rural cooperative medical system has made much progress, and recognized by the local residents (Table 4).

\begin{tabular}{|c|c|c|}
\hline Items Education level & Yulong, LiJiang, China & $\begin{array}{l}\text { Hat Yai, Songkhla, } \\
\text { Thailand }\end{array}$ \\
\hline $\begin{array}{l}\text { County hospital in China vs district hospital } \\
\text { in Thailand }\end{array}$ & $\begin{array}{l}\text { Bachelor degree } 94 \text { (42\%), below } \\
\text { bachelor }(58 \%)\end{array}$ & $\begin{array}{l}\text { Bachelor degree or } \\
\text { higher } 21(100 \%)\end{array}$ \\
\hline $\begin{array}{l}\text { Township hospital in China vs subdistrict } \\
\text { hospital in Thailand }\end{array}$ & $\begin{array}{l}\text { Bachelor degree } 31(12 \%) \text {, below } \\
\text { bachelor } 225(88 \%)\end{array}$ & $\begin{array}{l}\text { Bachelor degree } 20 \\
(100 \%)\end{array}$ \\
\hline Production of doctor/nurse/pharmacist/dentist & $\begin{array}{l}\text { Seriously insufficient senior } \\
\text { professional titles: nurse \& medical } \\
\text { technician, pharmacist in most of } \\
\text { township hospitals }\end{array}$ & $\begin{array}{l}\text { Need more doctors, } \\
\text { pharmacists, dentists } \\
\text { and supporting staffs }\end{array}$ \\
\hline Training & $\begin{array}{l}\text { Attended training } 336(70 \%) \\
\text { Never participated } 144(29 \%)\end{array}$ & $\begin{array}{l}\text { Opportunity according } \\
\text { to responsibility at least } \\
\text { once a year }\end{array}$ \\
\hline Motivation to work & $\begin{array}{l}\text { Satisfied } 192(40 \%) \\
\text { Not satisfied } 288(14 \%)\end{array}$ & $\begin{array}{l}\text { Work long time with } \\
\text { pleasure }\end{array}$ \\
\hline Salary & $\begin{array}{l}\text { Mostly } 1500-1999 \text { Yuan } \\
\text { Standard salary is low }\end{array}$ & $\begin{array}{l}\text { Higher than other } \\
\text { professional groups in } \\
\text { the city }\end{array}$ \\
\hline $\begin{array}{l}\text { Opportunities for further study / develop a } \\
\text { career }\end{array}$ & Difficult to improve professional skill & $\begin{array}{l}\text { Opportunity for all staff } \\
\text { with or without funding } \\
\text { support }\end{array}$ \\
\hline
\end{tabular}

\begin{tabular}{|c|c|c|}
\hline Item & Yu Long ,Lijiang, China & Hat Yai, Songkla,Thailand \\
\hline Study site & 16 Counties, 20 Villages & $\begin{array}{l}\text { Sub-district: } \\
\text { Chalung, Thungtumsao } \\
6 \text { villages }\end{array}$ \\
\hline Sample size & $\begin{array}{l}300 \text { households covering } 1186 \\
\text { individuals }\end{array}$ & $\begin{array}{l}211 \text { households covering } 946 \\
\text { individuals }\end{array}$ \\
\hline No. of household members & $3.95 \pm 3.05$ & $4.5 \pm 2.06$ \\
\hline Average income (Yuan) & $4479 \pm 4861$ & $3904 \pm 1952$ \\
\hline Family with disability people & $26(8.7 \%)$ & $22(10.4 \%)$ \\
\hline
\end{tabular}

\begin{tabular}{|c|c|c|}
\hline Item & Yu Long ,Lijiang, China & Hat Yai, Songkla,Thailand \\
\hline Health insurance & $\begin{array}{l}\text { New Rural Cooperative Medical } \\
\text { Scheme (NRCMS): } \\
1129(94.6 \%) \\
\text { Others: } 57(5.4 \%)\end{array}$ & $\begin{array}{l}\text { UC: } 787(83.2 \%) \\
\text { SSS: } 90(9.5 \%) \\
\text { CSMBS: } 48(5.1 \%)\end{array}$ \\
\hline $\begin{array}{l}\text { Health facility you usually go } \\
\text { to when you are sick }\end{array}$ & $\begin{array}{l}\text { County hospital: } 13.8 \% \\
\text { Village hospital: } 24.9 \% \\
\text { Private hospital/clinic: } 1.4 \% \\
\text { Township hospital: } 28.9 \% \\
\text { Provincial hospital: } 2.6 \%\end{array}$ & $\begin{array}{l}\text {-General hospital: } 51.9 \% \\
\text {-Sub-district health promotion hospital: } \\
41.9 \% \\
\text {-Private hospital/clinic: } 8.0 \% \\
\text {-PSU hospital: } 3.0 \% \\
\text {-Community hospital: } 1.5 \% \\
\text {-Provincial hospital: } 0.003 \%\end{array}$ \\
\hline $\begin{array}{l}\text { Main reason for seeking } \\
\text { treatment health facility }\end{array}$ & Close distance: $48.0 \%$ & Under insurance scheme: $64.7 \%$ \\
\hline $\begin{array}{l}\text { The financial burden of } \\
\text { patients }\end{array}$ & $8 \%$ Catastrophic health payment & Patients have only minimal financial burden \\
\hline
\end{tabular}


The residents of Yulong consider nearest hospital and convenient value most when they look for outpatient service (Table 5). But the residents of Hat Yai city in Thailand consider whether the hospital is medical insurance fixed point hospital or not when they look for outpatient service.

\begin{tabular}{|c|c|c|c|}
\hline Knowledge & Clear & $\begin{array}{l}\text { Partial } \\
\text { know }\end{array}$ & $\begin{array}{l}\text { Don't } \\
\text { know }\end{array}$ \\
\hline $\begin{array}{l}\text { 1. Which facilities } \\
\text { are included in the } \\
\text { contracted units of } \\
\text { NCMS? }\end{array}$ & $\begin{array}{l}620 \\
(52.3)\end{array}$ & $375(31.6)$ & $191(16.1)$ \\
\hline $\begin{array}{l}\text { 2. What certificates } \\
\text { are necessary for } \\
\text { reimbursement of } \\
\text { NCMS? }\end{array}$ & $\begin{array}{l}709 \\
(59.5)\end{array}$ & $285(24.0)$ & $192(16.2)$ \\
\hline $\begin{array}{l}\text { 3. What are the co- } \\
\text { payment ratio for } \\
\text { hospitalization in } \\
\text { county and township } \\
\text { hospital? }\end{array}$ & $\begin{array}{l}447 \\
(37.7)\end{array}$ & $316(26.6)$ & $423(35.7)$ \\
\hline $\begin{array}{l}\text { 4. What is the } \\
\text { ceiling line of NCMS } \\
\text { reimbursement for } \\
\text { one person per year? }\end{array}$ & $\begin{array}{l}184 \\
(15.5)\end{array}$ & $334(28.2)$ & $668(56.3)$ \\
\hline $\begin{array}{l}\text { 5. Which person or } \\
\text { family can apply for } \\
\text { MFA? }\end{array}$ & $\begin{array}{l}159 \\
(13.4)\end{array}$ & $294(24.8)$ & $733(61.8)$ \\
\hline $\begin{array}{l}\text { 6. What is the } \\
\text { procedure to admit } \\
\text { at non-home county } \\
\text { hospital? }\end{array}$ & $\begin{array}{l}121 \\
(10.2)\end{array}$ & $268(22.6)$ & $797(67.2)$ \\
\hline $\begin{array}{l}\text { 7. What is the } \\
\text { procedure to } \\
\text { reimburse at non- } \\
\text { home county } \\
\text { hospital? }\end{array}$ & $\begin{array}{l}125 \\
(10.5)\end{array}$ & $229(19.3)$ & $832(70.2)$ \\
\hline Average ratio (\%) & 28.5 & 25.3 & 46.2 \\
\hline
\end{tabular}

Table 5. Awareness of Health Insurance System (Hat Yai, Songkla, Thailand).

\begin{tabular}{llll|}
\hline Knowledge & Clear & $\begin{array}{l}\text { Partial } \\
\text { know }\end{array}$ & $\begin{array}{l}\text { Don't } \\
\text { know }\end{array}$ \\
$\begin{array}{l}\text { 1. In case of ordinary } \\
\text { illness, where to } \\
\text { receive medical } \\
\text { treatment free of } \\
\text { charge ? }\end{array}$ & $\begin{array}{l}183 \\
(86.7)\end{array}$ & $\begin{array}{l}22 \\
(10.4)\end{array}$ & $6(2.8)$ \\
$\begin{array}{l}\text { 2. In case of } \\
\text { emergency illness }\end{array}$ & & & \\
$\begin{array}{l}\text { or accident, where } \\
\text { to receive medical } \\
\text { treatment free of } \\
\text { charge ? }\end{array}$ & 140 & 49 & 22 \\
& & & \\
& & &
\end{tabular}

\begin{tabular}{|llll|}
$\begin{array}{l}\text { 3. The incurred } \\
\text { expenses in case to be } \\
\text { admitted at a hospital }\end{array}$ & $\begin{array}{l}106 \\
(50.2)\end{array}$ & $\begin{array}{l}52 \\
(24.6)\end{array}$ & $\begin{array}{l}53 \\
(25.1)\end{array}$ \\
$\begin{array}{l}\text { 4. Documents to bring } \\
\text { to the hospital }\end{array}$ & $\begin{array}{l}182 \\
(86.3)\end{array}$ & $\begin{array}{l}26 \\
(12.3)\end{array}$ & $3(1.4)$ \\
$\begin{array}{l}5 . \text { What case that need } \\
\text { to pay money for self } \\
\text { care ? }\end{array}$ & 90 & 49 & 72 \\
$\begin{array}{l}\text { Average ratio(\%) } \\
\text { Comparison of the two } \\
\text { places }\end{array}$ & 66.4 & 18.8 & 14.8 \\
$P$ value & 6.122 & 37.572 & 3.777 \\
\hline
\end{tabular}

\section{DISCUSSION}

Yunnan province is one of relatively poor frontier provinces in China, and also is one of the few ethnic enclave provinces. There are 25 unique nationalities in Yunnan among 56 ethnic groups of the whole country. 1 Yulong Naxi autonomous county is the only Naxi autonomous county of China, and located in the northwest of Yunnan province. It covers an area of 6198.76 square kilometers, jurisdiction over 16 townships, and the total population is 218700 people, including ethnic minority population of 187900 people, $85.9 \%$ of the population. ${ }^{2}$ The main difficulties at present are: Firstly is the lack of qualified health personnel, especially lack of high quality health technical personnel. The rural health service personnel are mainly composed of the primary health personnel. ${ }^{3}$ Secondly is the health personnel's technical level is not high, needs to be further improved. Thirdly is the relatively unreasonable health human resource structure and distribution. Personnel with bachelor degree or above are mainly concentrated in county hospital. ${ }^{4}$ Fourthly is the shortage of necessary medical equipments. Fifthly is the relatively insufficient health input. It is necessary to further intensify policy tilt.

Thailand has a long history in the development of rural health system and rural health human resources, and also has more successful experience in the health funding and forced doctors to work in the countryside. In 1967, in response to the condition of lack of rural doctors, the Thai government implemented a policy which sent new graduate medical students to work in rural areas for 3 years compulsorily, enrolled more rural background medical students, set up medical colleges outside big cities, and arranged students to do rotational internship in rural medical institutions during study period. ${ }^{5}$ More than two-thirds of the medical students worked in the countryside after graduation. On this basis, a series of combined policy implementation, ${ }^{6-8}$ began gradually from 1975, implemented the compulsory service and 
rural doctor incentives policies. Thailand implemented "rural doctor joint expansion project" in 1995 and "one region, one doctor" project in 2005. In the past 40 years, Thailand has trained a large number of health care personnel after system training to serve the public during social and economic transformation, and rural health workers also got a large number of international organizations sponsorships. Over the years, most of them went back to work in the countryside, and thus rural health service has been significantly improved. In order to ensure a more fair education, more and more students, recruited on long term basis, went to rural areas to meet the needs of the locals. New medical students from rural areas were recruited and trained in the provincial hospital. In 2001, the Thai government adopted a policy of universal insurance, and health insurance coverage is now close to $100 \%$, which greatly improved the health service utilization. ${ }^{9}$ Thailand was evaluated as one of "low cost, great health benefit countries" by the World Health Organization in 2010. Songkhla province, one of the southern provinces of Thailand, which is located in the east of the Malay Peninsula, covers an area of 7393 square kilometers, has 14 regions, each region has a community hospital with 30 to 60 beds. Hat Yai, a major city of Songkhla Province, has about 800000 people, close to the border of Malaysia, is also the second largest city in Southern Thailand. The premise_of Songkhla University is located in the Hat Yai, which was established in 1972. It played an important role for providing health human resources in Southern Thailand.

Good policy mechanism is the guarantee, we should cultivate rural medical staffs who can go, retain and used in local remote areas. Due to the inherent differences between urban and rural areas in China, such as medical security and health financing, the allocation of resources, service providing, etc, lead to health outcomes inequality between urban and rural residents. ${ }^{10}$ The reason is that some specific preferential policies have not been implementation. At present the medical colleges and universities and local hospitals are jointly training rural doctors in Yunnan province. It is not only beneficial to upgrade the rural doctors knowledge about home health care situation, strengthen the sense of responsibility service for their hometown, but also can enhance the comprehensive strength of the local hospitals, strengthen basic medical services, however, to achieve this goal, there must be more financial support from central and local government policies.

According to relevant documents of national Ministry of Health, Health Department and Department of Education in Yunnan province, ${ }^{11}$ Kunming Medical University has been cultivating directional state planning order for 100 people a year since 2010, has enrolled 5 sessions of students until now, the students plan order directional counting at school is 500 in total, including 234 boys, accounting for $46.80 \%, 266$ girls, accounting for $53.20 \%$. All of them are general medicine undergraduate students, length of schooling for five years. The orientation for Lijiang city is 25 people.

Increase the supply of human resources for health, strengthening on-the-job personnel raining. Rural health human resources in Songkhla Province of Thailand is more adequate than in China, education level of village doctors is also higher than China's. The doctors have been increased from 8000 in 1984 to 35000 in 2009, grew by more than four times, at the same time the nurse quantity also increased 3.3 times. The implementation of "Rural Doctors Expansion Planning (1994)" and "one County, one Doctor Program (2004)" has played a positive role in promoting the growth of doctors in rural areas. In 2004, in response to the shortage situation of rural health manpower, the Thai government decided to increase enrollment of 700 medical students every year, and plans to increase 10000 doctors within 15 years.

Increase in health investment, implementing compulsory public service policy. In 2011, the Thai health expenditures accounted for $9 \%$ of GDP, and China was only $4.8 \%$, far higher than that of China. Its health insurance coverage is very high, reaching $99.5 \%$ in 2010. Compulsory public service policy began in 1972 , and the purpose is to prevent the loss of health human resources from overseas. All medical students must work in the domestic public medical institutions for 3 years after graduation, and with ODOD Project students should work full 10 years, and offenders will be punished $\$ 13000$ (ordinary medical students and CPIRD project) or $\$ 65000$ (ODOD). Basic medical service is also one of the necessary conditions for residents continue to accept specialist training. In 1979, the Thai government launched the rural development plan, through a series of capital investment, greatly improving the rural medical service equipment, transportation, housing and other infrastructure, supplementary staffs of these agencies, in order to attract more human resources for health to work in the countryside. According to China health statistics yearbook 2010, compared with Thailand, our government health expenditure accounts for only $44.7 \%$ of the total for the resident's medical expenditure, less than $73.2 \%$ of Thailand. In the aspect of government health spending, per capita is far more, Thailand is $100 \mathrm{RMB}$, but our country is only $49 \mathrm{RMB}$. This shows that the serious inadequate health input of China government is one of the reasons for most residents cannot fully enjoy the basic medical insurance and public medical institutions welfare destination. 
To improve treatments of health care workers.

In order to motivate health workers in rural grassroots medical institutions, the Thai government started, in 1975, to issue $\$ 80 \sim \$ 108 /$ month as "special subsidy" for doctors in County Hospital. After 1997, the special subsidy amount was up to $\$ 500 /$ month for the doctor in the remote region, and this subsidy is almost equivalent to their fixed wage three times a month. In 1995, the government provided $\$ 400 /$ month "public institutions service allowance" for those doctors who did not work in the private hospitals. Thailand government also formulated the "about non-statutory working hours of overtime and relevant policy", in order to improve work enthusiasm of medical staff's.

To establish national health human resources development plan, in 2006, the ministry of public health of Thai announced the "national health human resources development planning" after solicit opinions from the parties, and gone through dozens of times of change. The plan analyzed health human resources condition of Thailand, summarized the problems and challenges faced by then, cleared about the national medium and long-term development targets about health human resource, and proposed the corresponding countermeasure and the expected results. It has designed a clear road map for the health human resources development of Thailand, and established a good education mode though the hospital training of rural doctors.

\section{CONCLUSIONS}

Evidence suggests that through comparison between Hat Hai of Thailand and Yulong of China, we can try to take some actions, such as increase the financial investment in health sector, make special preferential policies and improve the rural health workers treatment capabilities gradually, innovate mechanisms, and constantly improve the scientific and rational system of rural health human resource development, and strengthen the construction of rural health personnel, and continuously improve the overall quality of health personnel. These steps are important for the improvement of health human resources and health situation of China

\section{ACKNOWLEDGEMENTS}

This is a collaborative study conducted by Kunming Medical University (KMU) and Prince University of Songkla.(PSU). Contributions by the teachers from KMU and PSU and all medical postgraduates who participated in the surveys are recognized and appreciated; without them this study would not have been possible.

\section{Conflict of Interest: None}

Funding: This study is funded by China Medical Board (CMB) with grant number \#10-032

\section{REFERENCES}

1. Wang M, Fang H, Bishwajit G, Xiang Y, Fu H, Feng Z. Evaluation of Rural Primary Health Care in Western China: A Cross-Sectional Study. Int J Environ Res Public Health. 2015 Oct 29;12(11):13843-60. [PubMed | PMC | DOI]

2. Mao Yong, Zhou Jia, Xu Chuanzhi etc. The evaluation of the prevalence and burden of disease in rural poor mountainous areas of Lushui county . Modern preventive medicine.2011, 38 (1): 147-149. [Full Text]

3. Liu JA, Wang Q, Lu ZX. Job satisfaction and its modeling among township health center employees: a quantitative study in poor rural China. BMC Health Serv Res. 2010 May 10;10:115. [ubMed | PMC | DOI]

4. Zhang L, Yap L, Xun Z,4 Zunyou Wu, Wilson DP. Needle and syringe programs in Yunnan, China yield health and financial return. BMC Public Health. 2011; 11: 250. [PMC | DOI]

5. World Health Organization. Increasing Access to Health Workers in Remote and Rural Areas through Improved Retention: Global Policy Recommendations. Geneva: World Health Organization. 2010. [Full Text]

6. Patcharanarumol W, Tangcharoensathien V, Limwattananon S, Panichkriangkrai W, Pachanee K, Poungkantha W, Gilson L, Mills A. Why and how did Thailand achieve good health at low cost? In 'Good Health at Low Cost' 25 Years on What Makes a Successful Health System? 1st edition. Edited by Balabanova D, McKee M, Mills A. London: London School of Hygiene \& Tropical Medicine.2011:193-223. [Full Text]

7. Wibulpolprasert S, Pachanee C. Addressing the internal brain drain of medical doctors in Thailand: the story and lesson learned. Global Social Policy. 2008, 8(1):12-15. [Full $\underline{\text { Text] }}$

8. Wibulpolprasert S, Pengpaibon P. Integrated strategies to tackle the inequitable distribution of doctors in Thailand: four decades of experience. Hum Resour Health .2003, 1(1):12. [MC $\mid \underline{\mathrm{DOI}}]$

9. Tangcharoensathien V, Prakongsai P, Limwattananon S, Patcharanarumol W, Jongudomsuk P. From targeting to Universality: lessons from the health system in Thailand (Chapter 16). In Building decent societies: rethinking the role of social security in development. Edited by Townsend P. Houndmills, Basingstoke, Hampshire: Palgrave Macmillan. 2009:310-322. [Full Text]

10. Yip WC, Hsiao W, Chen W, Hu S, Ma J, et al (2012). Early appraisal of China's huge and complex health-care reforms. Lancet, 379:833-42. [ $\underline{\text { PubMed } \mid \text { DOI] }}$

11. Chinese Health Statistical Digest. 2012. Beijing: Ministry of Health, People's Republic of China. 2012. p.68. [Full Text] 